\title{
Slide origin of breccia lenses in the Cambrian of the North China Platform: new insight into mass transport in an epeiric sea
}

\author{
A.J. (Tom) van Loon'1, Zuozhen $\mathrm{Han}^{2}$, Yu Han ${ }^{3}$ \\ ${ }^{1}$ Geological Institute, Adam Mickiewicz University, Maków Polnych 16, 61-606 Poznan, Poland; \\ e-mail: tvanloon@amu.edu.pl; tom.van.loon@wxs.nl \\ ${ }^{2}$ College of Geological Science and Engineering, Shandong University of Science and Technology, Qingdao 266510, \\ China; e-mail: hanzz@126.com \\ ${ }^{3}$ School of Earth Sciences and Resources, China University of Geosciences, Beijing 100083, China; \\ e-mail: hanyu.8866@163.com
}

\begin{abstract}
An oolite in the Furongian (Late Cambrian) Chaomidian Formation in Shandong Province, China, which was deposited on the North China Platform in an epeiric sea, contains several limestone breccia lenses of various dimensions (centimetres to decimetres thick and decimetres to more than 10 metres in length) in an E-trending section. The oolite, which is approximately $40 \mathrm{~cm}$ thick, was originally thicker, as indicated by a planar truncation surface that formed by wave abrasion. The breccia lenses in this oolite are generally mound-shaped with a flat base and a convex top. The western margin of the lenses is commonly rounded whereas the eastern margin commonly has a tail (consisting of a rapidly eastwards thinning breccia horizon that gradually ends in a horizon of isolated clasts). Some of the breccia lenses are underlain by a shear zone.

The formation of the breccia lenses cannot be easily explained by normal depositional or deformational processes. It is concluded that the lenses represent fragments of a partly consolidated layer, consisting of both rounded and angular platy clasts, which slid down over a very gently inclined sedimentary surface which acted - possibly together with a water film - as a lubricant layer. During transport, the layer broke up into several discrete bodies that formed small 'highs' at the sedimentary surface of the shallow epeiric sea. Subsequently, waves partially eroded the lenses, mostly at their margins, producing their mound-shaped form.

Sliding of blocks is known from a wide variety of environments in the sedimentary record; however, this is the first description of the sliding of blocks in an epeiric sea. This indicates that such a low-relief submarine carbonate setting is, like its siliciclastic counterparts, susceptible to this process.
\end{abstract}

Keywords: breccia lenses; sliding; epeiric sea; Chaomidian Formation; Furongian; North China Platform

\section{Introduction}

Epeiric seas are characterised by predominantly quiet depositional conditions (occasionally interrupted by storms that may lead to waves that can disturb the bottom of the shallow sea), and by a relatively low relief of the sea bottom. These conditions lead to low-energy accumulation of a sedimentary succession in which mass-transported layers are commonly absent or rare. The North China Platform is a representative example (Chen et al., 2011, 2012). It formed on a stable craton, the Sino-Korean Block (Meng et al., 1997) (Fig. 1A), and the 
Cambrian-Ordovician of the platform consists of a thick succession of mixed siliciclastic and carbonate deposits (Meng et al., 1997; Chough et al., 2010) (Fig. 1B). The upper part of the Cambrian succession (Chaomidian Formation) consists mainly of various carbonate deposits (e.g., lime mudstone, wackestone to grainstone, microbialites), and, as common in carbonate successions of epeiric seas, especially a number limestone breccias and conglomerates (Chen et al., 2009a, 2009b, 2011). Intraformational limestone breccias and conglomerates in platforms are commonly formed either by waves affecting the sea floor, by intrastratal cracking due to cyclic wave loading (probably during extreme storms) (Chen et al., 2009a), or by secondary, early-diagenetic processes such as soft-sediment deformation (e.g., Bouchette et al., 2001; Chough et al., 2001; Kwon et al., 2002; Chen et al., 2009a, 2009b). The Jiulongshan breccia layers do not show any sign of breaking up as a result of seismic shocks; for the major part they show signs of transport (so that intrastratal cracking as a result of wave-induced loading, although present, cannot be the cause of most breccias). It is therefore most likely that most breccias are due to storm waves that affected the bottom of the epeiric sea, which was situated below fair-weather base, as proven by the frequent occurrence of (not often dolomitised) micritic lime mudstones.

One of the oolitic grainstones in the Jiulongshan section (Fig. 1A) contains lenses of breccias of different sizes; these lenses range in length from a few decimetres to several metres. They are mound- to teardrop-shaped, have a tail, and are commonly underlain by a shear zone; the characteristics of both the tails and the shear zone will be detailed in the section devoted to the description of the lenses. The present contribution provides an interpretation for the formation of the lenses, which are distinct from other limestones in the Chaomidian Formation, and which are also considered to represent a hitherto unknown feature from epeiric seas, thus deepening our insight into the processes affecting the sediments formed in this geologically important environment.

Although we use the term 'breccia lenses', this is not entirely correct, because - in addition to truly angular clasts - clasts also (and even more commonly) occur with rounded edges.
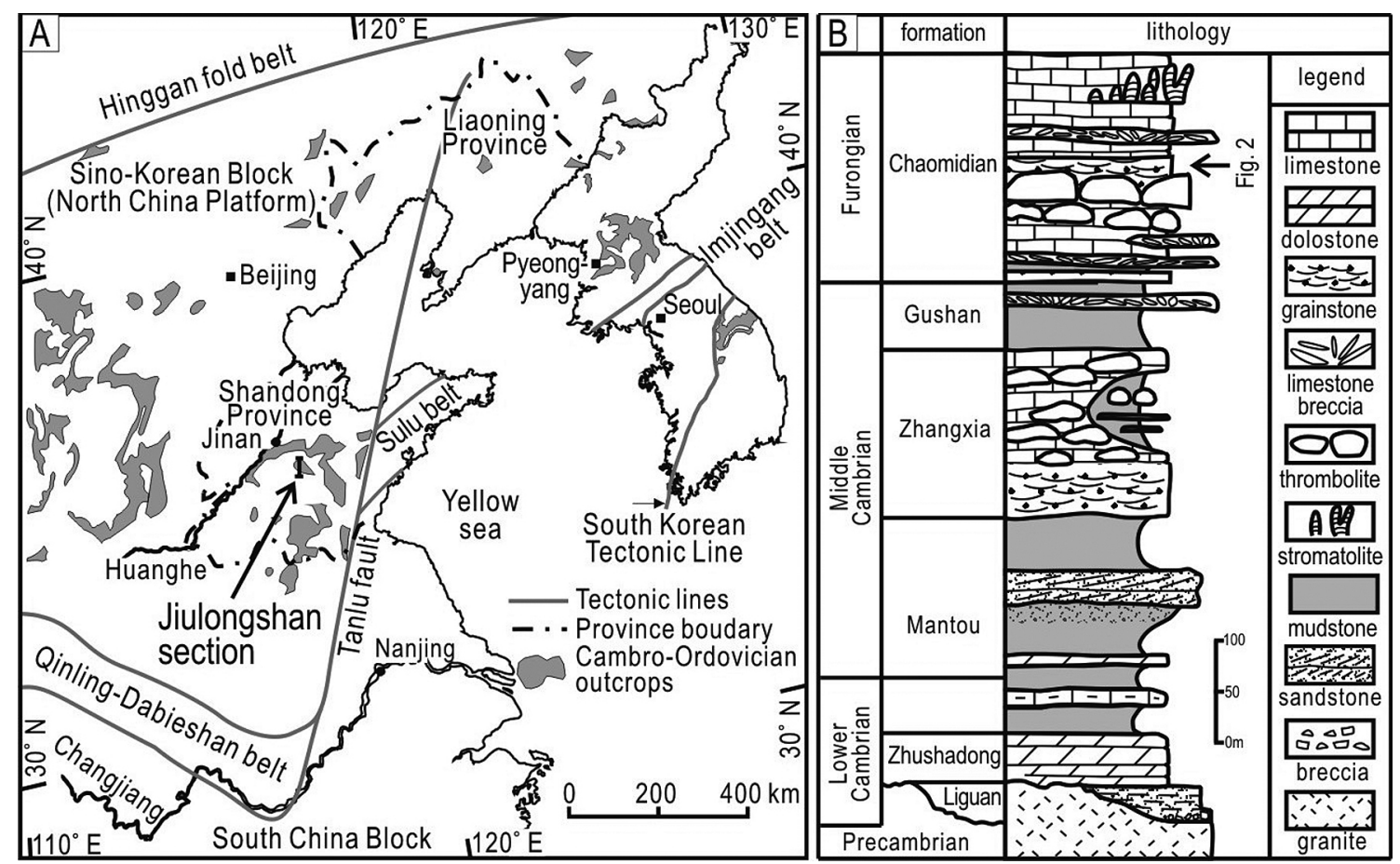

Fig. 1. Characteristics of the study area.

A: Location map of the study area (modified after Chen et al., 2009a).

B: Schematic Cambrian lithostratigraphy in Shandong Province, China. 
The common occurrence of angular fragments makes the term 'conglomerate' also incorrect, however. For the sake of simplicity these breccia/conglomerate intermediates will be called 'breccias' here.

\section{Geological setting}

The study area in the south-western part of Shandong province belongs to the Luxi Block, which forms part of the Sino-Korean Block. The Cambro-Ordovician forms a succession of some $1800 \mathrm{~m}$ thick; it consists of siliciclastic and carbonate deposits, which have been studied stratigraphically and sedimentologically in much detail in this province (Meng et al., 1986; Wang et al., 1989; Mei et al., 1996; Shi et al., 1997; Mei \& Ma, 2001; Chen et al., 2009a, b, 2011, 2012; Chough et al., 2010) because they are well exposed here.

The Cambrian, which rests unconformably on Precambrian granite and gneiss, consists of carbonates and siliciclastics, subdivided into six formations (Fig. 1 B), of which the Chaomidian Formation is the youngest. This formation, of which the thickness varies from some $200 \mathrm{~m}$ to some $300 \mathrm{~m}$, is overlain by the Early Ordovician Sanshanzi Fm. The carbon- ates/siliciclastics ratio increases upwards in the Cambrian (Fig. 1 B), and the Chaomidian Fm. consists almost exclusively of carbonates. These form limestone breccias, grainstones, wackestones, packstones and microbialites. All these sediments accumulated in a storm-dominated shallow-marine environments (Chen et al., 2011, 2012).

Detailed sections have been analysed at a 1:50 scale in two sections: the Tangwangzhai and the Jiulongshan section (Chen et al., 2011). For detailed logs of the section under study, the reader is referred to Chen et al. $(2011,2012)$. Remarkably, the presence of the breccia lenses inside an oolite did not receive any attention thus far.

The breccia type that constitutes the lenses in the oolite layer is oligomictic and has a marlstone matrix; some microbial infillings between some of the clasts are present, but they do not form a biogenic framework. The clasts consist of lime mudstone to wackestone (mainly micrite and peloids; bioclasts make up $<20 \%$ ); the marlstone matrix is (as indicated by XRD analysis) composed of micrite, dolomite and some siliciclastics (clay minerals and very fine quartz grains). The clasts in this type of breccia have almost all the same composition as the (commonly thin) layer underneath. They are
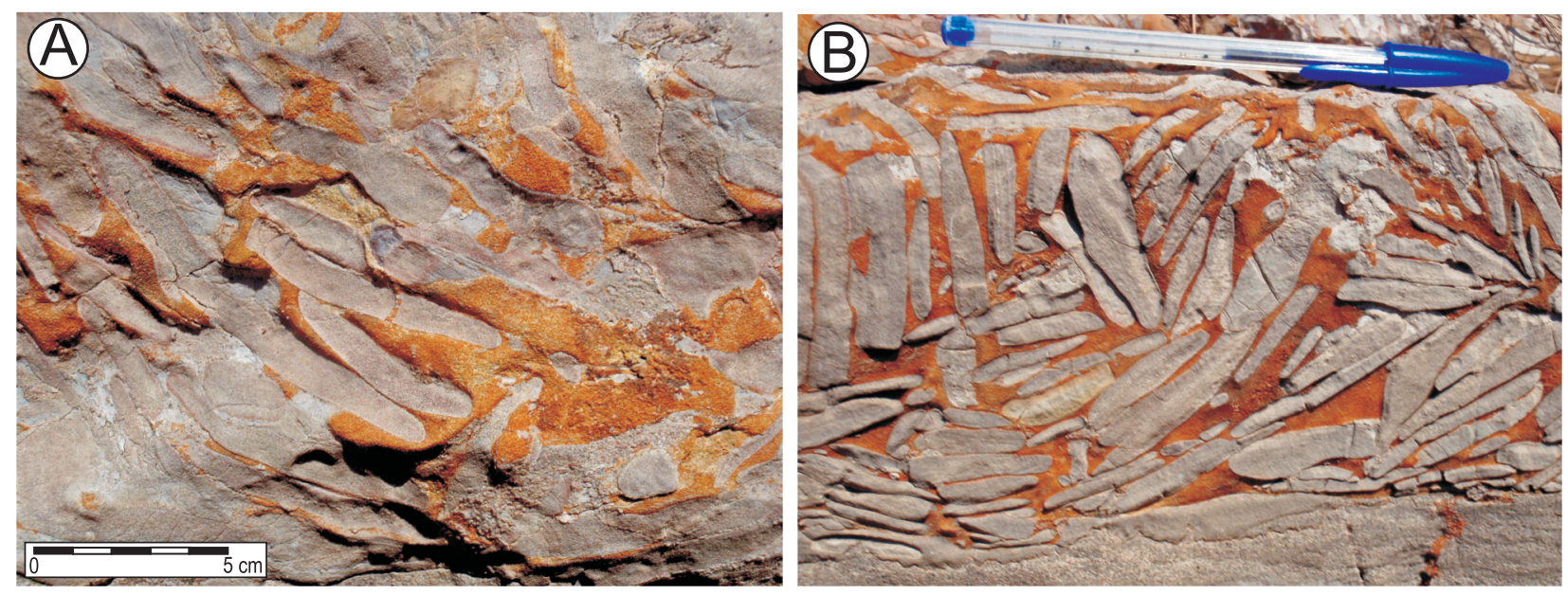

Fig. 2. Characteristics of the breccia clasts.

A: Slightly bent platy clasts prove a (semi)consolidated conditions during the diagenetic stage when the breccias originated, but before the breccia layer started sliding and became fragmented.

B: Many of the breccias in the Jiulongshan section show (sub)horizontal platy clasts at the bottom, slightly to steeply inclined clasts in their middle part, and (sub)vertical clasts in their upper part. This occurred before the not yet consolidated breccia became fluidized due to upward water/sediment escape under high pressure (see Van Loon et al., in press). Before the breccia layer became fragmented, it had become semi-consolidated. 
platy (i.e., the a- and b-axes are several times longer than the c-axes) and may be angular, subangular or subrounded; in some cases they are even well rounded. Although the majority of the clasts are flat, suggesting a consolidated or even lithified nature during the fragmentation process that resulted in a breccia, clasts of the same composition occur that show bending (Fig. 2A), proving that at least part of the clasts were not lithified during fragmentation. We therefore conclude that the layer from which the clasts were derived, was in a semi-consolidated to consolidated (but not lithified) state when the brecciation occurred.

These breccias tend to be clast-supported, and some show a remarkable fabric: mainly (sub)horizontal clasts in the lower part, inclined clasts in the middle part, and (sub)vertical clasts in the upper part (Fig. 2B). This remarkable fabric has been mentioned several times in the literature, but a satisfactory explanation was not published thus far; a detailed genetic analysis will be presented soon (Van Loon et al., in press).

The conditions under which these breccias were formed have, on the basis of the various facies of some of the carbonates, been described (e.g. Chen et al., 2009a) as partly a low-energy subtidal environment in which sediments accumulated below the fair-weather wave base. On the other hand, the stratified grainstones, the biohermal microbialites and some ripple crosslaminated limestones indicate, as do the 'normally' stratified breccias, high-energy conditions of the carbonate ramp (Meng et al., 1997).

The coarsest layers form breccias, conglomerates or a mixture of them. Brecciation under the conditions prevailing here has been ascribed to burial fragmentation of early cemented carbonate mud, liquefaction of carbonate sands, and injection of uncemented argillaceous mud, followed by mobilization of the fragmented clasts (Chen et al., 2009a). The fragmentation has been ascribed to an external trigger, most probably storm-wave loading, a process that is well known to have frequently affected the bottom of epeiric seas (see, e.g. Spengler \& Read, 2010); the mobilization of the clasts in the breccia layers has been ascribed to prolonged compactional pressure due to progressive sedimentation and burial (Kwon et al., 2002).

Whatever the precise processes resulting in the breccias with (sub)vertical clasts may be, one layer of such a breccia seems to have been broken up, now forming lenses inside an oolite. The process by which the lenses became embedded in an oolite is the subject of the present study.

\section{Description of the lenses}

The breccia lenses occur in a crudely stratified oolite, approx. $40 \mathrm{~cm}$ thick, that is underlain by a stratified conglomerate (the platy limestone clasts are for the large majority well rounded and have roughly bed-parallel positions, suggesting breaking up of a limestone layer, probably by wave action) and that is overlain by yellowish-green shale containing limestone nodules. The oolite is a grainstone consisting mainly of ooids, peloids, abraded fossil fragments, and abundant glauconitic grains.

Eight breccia lenses are exposed in an E-W $\left(085^{\circ}-265^{\circ}\right)$ trending wall of the Jiulongshan

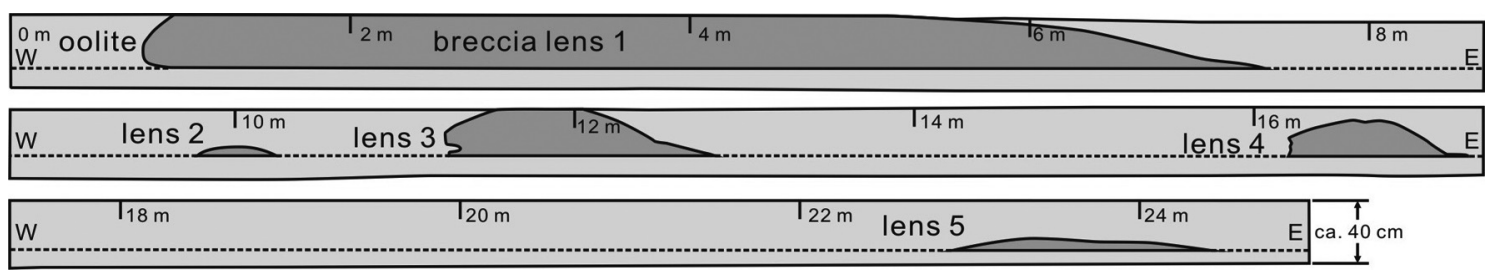

Fig. 3. Overview of the oolite (light grey) with the five easternmost breccia lenses (numbered 1-5) (dark grey). The uppermost section shows the western part of the section under discussion, whereas the lowermost section shows the easternmost part (see the 2-m interval indications). Three more, comparable, lenses occur to the west of the upper diagram, the largest one being approx. $12 \mathrm{~m}$ long. These three westernmost lenses are not depicted here because they show characteristics that are identical to the five depicted here and described in the text. 
section (Fig. 3). All these lenses have an identical composition and fabric with a flat, slightly irregular base and a mound- to teardropshaped geometry (Figs 4-5A). The top of the lenses show vertically orientated clasts that commonly have been truncated at their top parts (Fig. 5B). The base of all eight lenses is situated at the same level in the oolite. This level can be traced from one breccia lens to another within the oolite because of the presence of a horizon (Fig. 6) with mainly angular fragments of the same composition as the clasts and matrix of the breccias and the oolite in which the breccia lenses are hosted. This level cannot be regarded as a basal conglomerate of a transgression, not only because fragments of other rock types that would have been eroded are missing, but also because too many fragments are angular. The horizon with the fragments cannot represent a phase of emergence either, as there are no indications of subaerial weathering or pedogenesis; neither do the fossil fragments in the oolite below nor above this horizon indicate such shallow conditions (their assemblage indicates a subtidal position).

The breccia lenses tend to have a broadly rounded outline at their western ends and a tail (the tails are dealt with in detail below) on the eastern side of the lenses (Fig. 7). They are thickest in their middle part and thin towards the east (Fig. 7). They consist of oligomictic pebble- to cobble-sized platy, subangular to subrounded clasts of peloidal grainstone. Their matrix is composed of micritic limestone and dolomitic marlstone, as well as some ooids, both angular and abraded fossil fragments (trilobites, echinoderms, brachiopods, and algae), peloids, and glauconitic grains. Both clasts and matrix are truncated along the upper boundaries of the breccia lenses (Fig. 5B).

The three westernmost lenses have characteristics that are identical to those of some of the five eastern lenses, apart from the fact that they originally must have had, like lenses 1 and 3 (Fig. 3), a height that surpassed the present thickness of the oolite layer in which they are embedded, and that their top parts have consequently been abraded to the same level as this oolite layer, just like lenses 1 and 3 . Because of the general resemblance, these three westernmost lenses will not be described here in detail; let it suffice here to mention that the westernmost lens is the largest of all, with a width (or a length) of some $12 \mathrm{~m}$. The five lenses dealt with in more detail here are numbered in the following 1-5, from west to east (Fig. 3).

Lens 1 is $6.58 \mathrm{~m}$ wide and has a maximum thickness of $33 \mathrm{~cm}$. Its westernmost part is

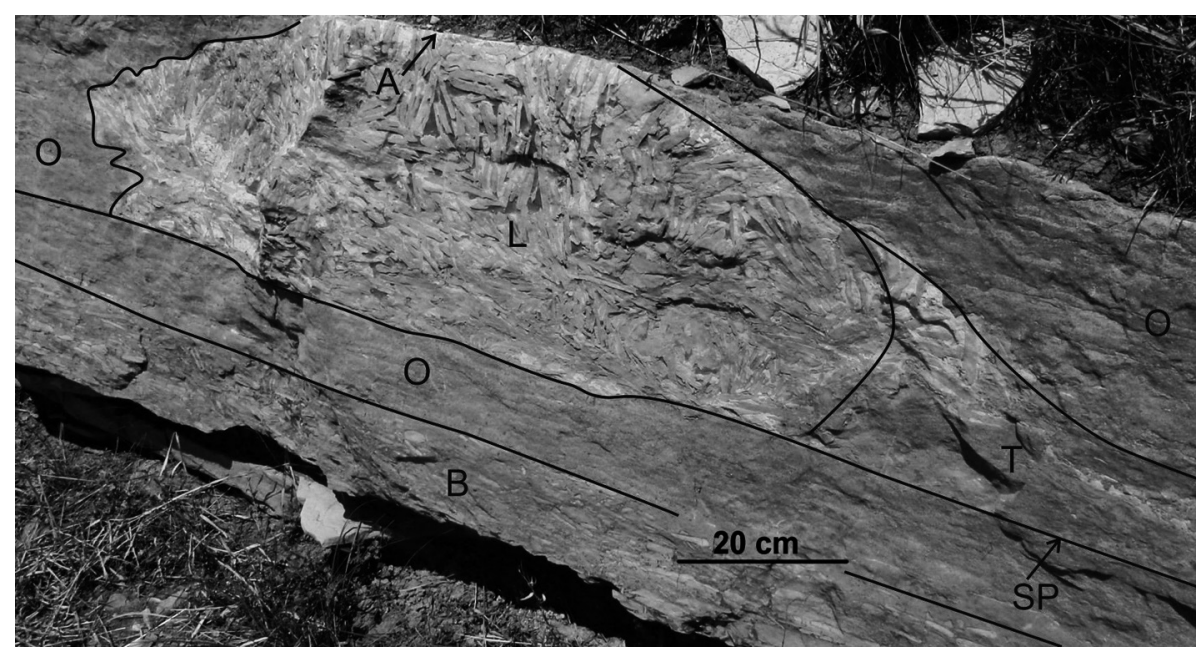

Fig. 4. Breccia Lens 3 (L). The matrix is coloured orange-brown. Note the flat lower boundary (sliding plane, SP) with the underlying oolite $(\mathrm{O})$; the boundary between the oolite and the underlying breccia $(\mathrm{B})$ is also plane and may represent an abrasion level. The top of the breccia lens $(\mathrm{L})$ is abraded in its middle part $(\mathrm{A})$. The tail at the right $(\mathrm{T})$ seems to consist of particles broken off from the top part of the lens. Note that part of the tail is well visible thanks to the contrasting colour of light grey fragments, but that these form only part of the tail: fragments with a less contrasting colour also occur above and below these well visible grey fragments (see for details Fig. 9). 
covered by the 'host' oolite, but its thickness increases rapidly towards the east, so that no oolite cover is present. In its middle part it has been abraded to the same level as the oolite in which it is embedded. At its eastern end, the breccia lens thins again towards the tail and is overlain by the oolite. All over its up- per boundary, the great majority of clasts have a (sub)vertical position; most of the clasts are truncated due to the abrasion that affected the succession at this level. At the base of the lens, most clasts are orientated (sub)horizontally, and locally a more weathered zone with exclusively horizontal to subhorizontal clasts that
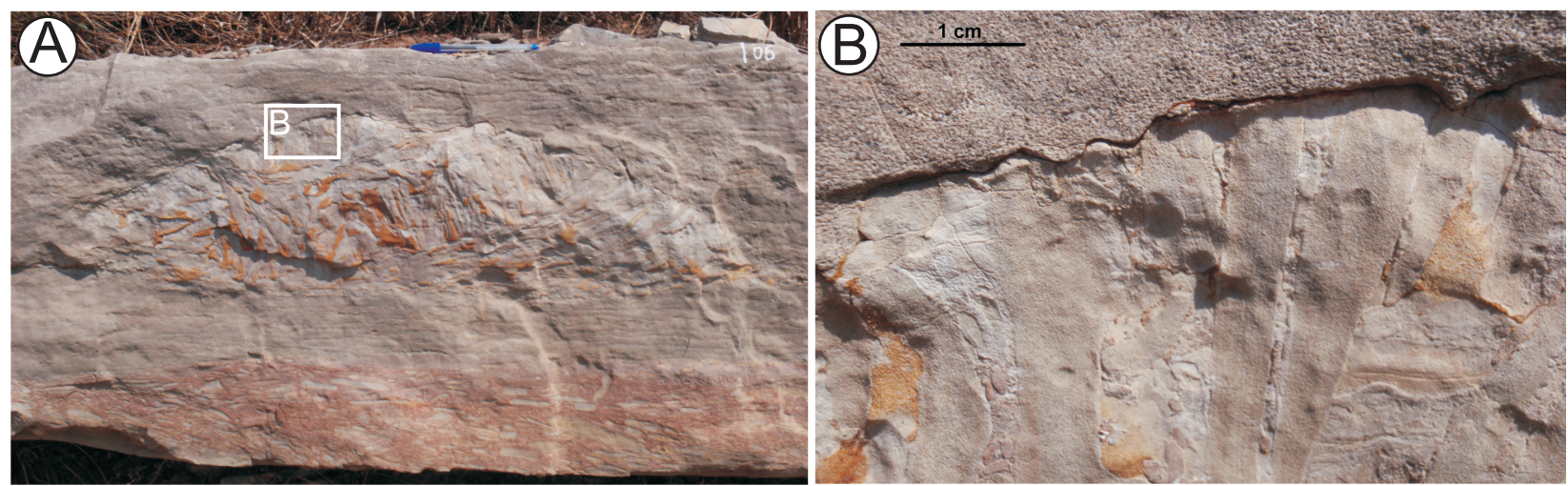

Fig. 5. Characteristics of Lens 4.

A: Main body of the lens. Note the flat lower boundary and the chaotic fabric with numerous more or less vertical limestone clasts.

B: Truncation of clasts at the top of the lens interpreted as abrasion by waves. The clasts were apparently slightly more resistant to the abrasion than the matrix of the breccia. The matrix between the large vertical clasts consists mainly of micrite with some small clasts that are sometimes well rounded, indicating that they underwent individual transport (or movement by waves) before they became embedded in the breccia.
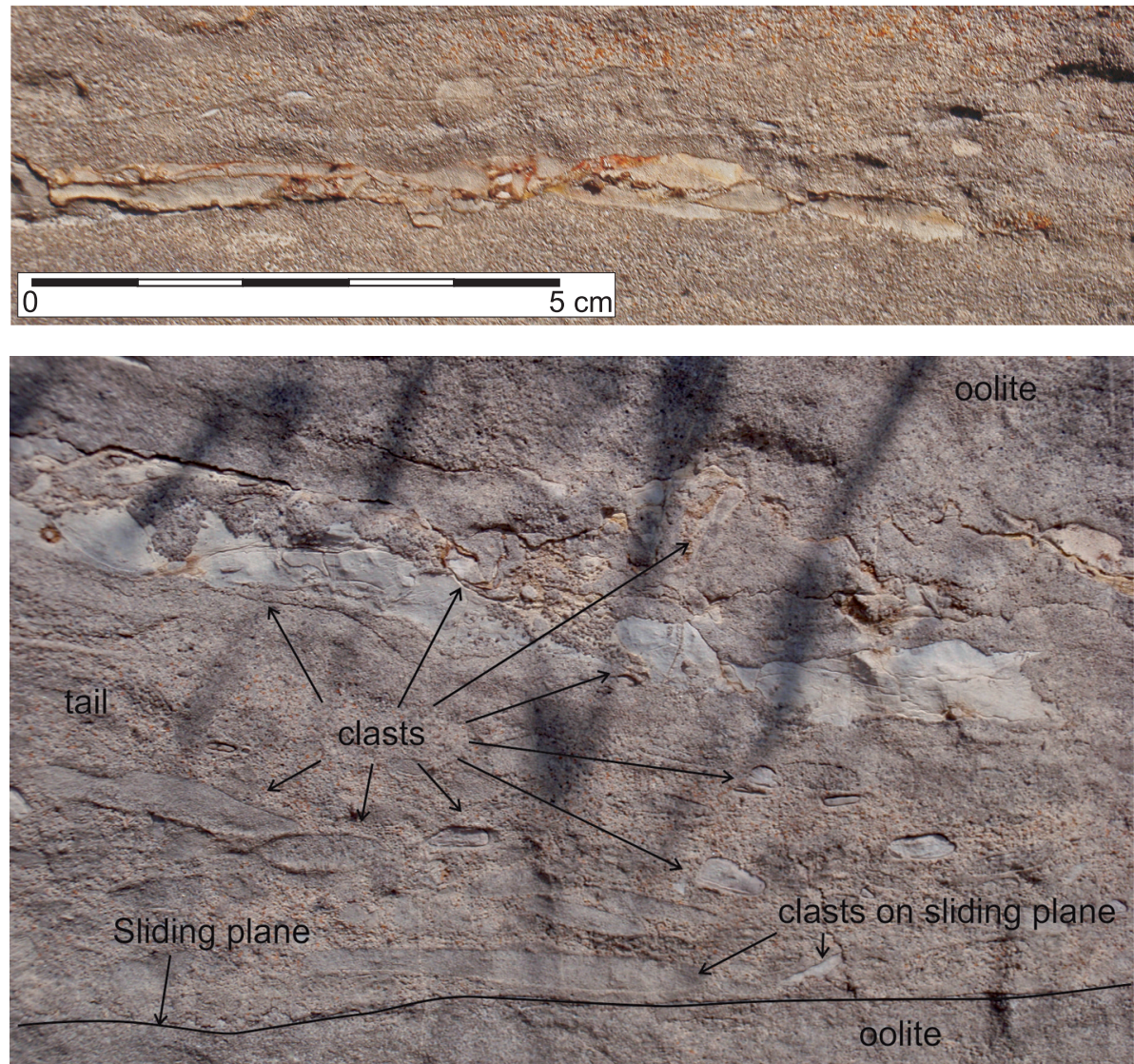

Fig. 6. A thin horizon characterised by fragments of the breccia lenses and the underlying oolite connects the bases of the breccia lenses.

Fig. 7. The tail ( $35 \mathrm{~cm}$ long) of Lens 3, which gradually thins to the east (= right). Note that the light grey fragments form only, because of their colour, the best visible part of the tail. Above and below the grey fragments, the tail consists of darker fragments (see arrows). The lowermost tail fragments are positioned at the same level as the base of the breccia lens. 
have been broken into small fragments (Fig. 8). The composition of the clasts includes breccia (both greyish wackestone and brownish dolomitised lime mudstone) and oolite, suggesting that it is a shear zone (the shear zone is detailed below).

Lens 2 (Fig. 3 ) is $45 \mathrm{~cm}$ wide and maximally $5 \mathrm{~cm}$ thick, showing a flat mound-shaped geometry. This small lens has neither a tail, nor a shear zone underneath. The clasts inside show relatively rarely a (sub)vertical orientation, and these clasts do not show truncation. In fact, the breccia shows much similarity to the lower part of the breccias in lenses 1, 3 and 4 .

Lens 3 (Figs 3, 4) is $132 \mathrm{~cm}$ wide and maximally $28 \mathrm{~cm}$ thick. The fabric is similar to that of Lens 1. The lens is mound-shaped (though with an abraded surface in the middle) with a flat bottom, and with a tail at its eastern end. The most obvious irregularity is at its western boundary, where oolite seems to penetrate the breccia. At this place, the overall horizontally stratified oolite penetrating the lens shows a vague lamination dipping eastwards, resembling the wedge-shaped structures that are formed in front of an advancing glacier that 'bulldozes' the sediments forward (cf. Morawski, 2009). A shear zone, consisting of clasts with horizontal or eastward-dipping orientations, underlies the breccia body, suggesting movement with a component from east to west.

Lens 4 (Figs 3, 5A, B), which is $91 \mathrm{~cm}$ wide and maximally $21 \mathrm{~cm}$ thick, resembles Lens 3 in almost each detail; since its height is less than that of the host oolite, its top has, however, not been abraded. This lens shows, like Lens
3, a westernmost boundary that is irregular. There is a shear zone visible under the breccia, and a tail is present, again on the eastern side. An interesting aspect of this lens is that $30 \mathrm{~cm}$ west of its western end, a small N-S trending section is exposed perpendicular to the general E-W trending wall. In this N-S trending section, part of the breccia lens is also visible (Fig. 9). It starts $5 \mathrm{~cm}$ north of the E-W trending exposure and shows part of a breccia lens of which a width of $35 \mathrm{~cm}$ is visible, with a maximum height of $28 \mathrm{~cm}$ at a place where the lens is still covered with $10 \mathrm{~cm}$ of oolite, but the thickness decreases rapidly to the north, strongly suggesting only a small northward extent. This configuration suggests an ESE-trending orientation of the breccia lens $\left(\sim 115^{\circ}\right)$.

Lens 5 (Fig. 3) has a much lower height/ width ratio than the other lenses. It is $142 \mathrm{~cm}$ long and maximally $7 \mathrm{~cm}$ thick. Most clasts of the breccia have a subvertical position, and the topmost clasts are truncated. The western boundary is irregular and the eastern side features a tail. No shear zone is visible.

\subsection{Characteristics of the tails}

The tails that all lenses (except Lens 2) show, are all present at the eastern end of the respective lenses. They resemble the tails that have frequently been described from slumps: they consist of fragments with the same composition as the lens, and they form a gradually thinning body that tends to approach the level in the oolite that forms the basis of the lenses.

Fig. 8. The shear zone underneath Lens 1 (visible part of pen $\sim 3$ $\mathrm{cm})$. The clasts consist of oolite of with the same composition as the underlying oolite, and of greyish wackestones and brownish dolomitised lime mudstones that have the same compositions as the clasts in the breccia lenses.

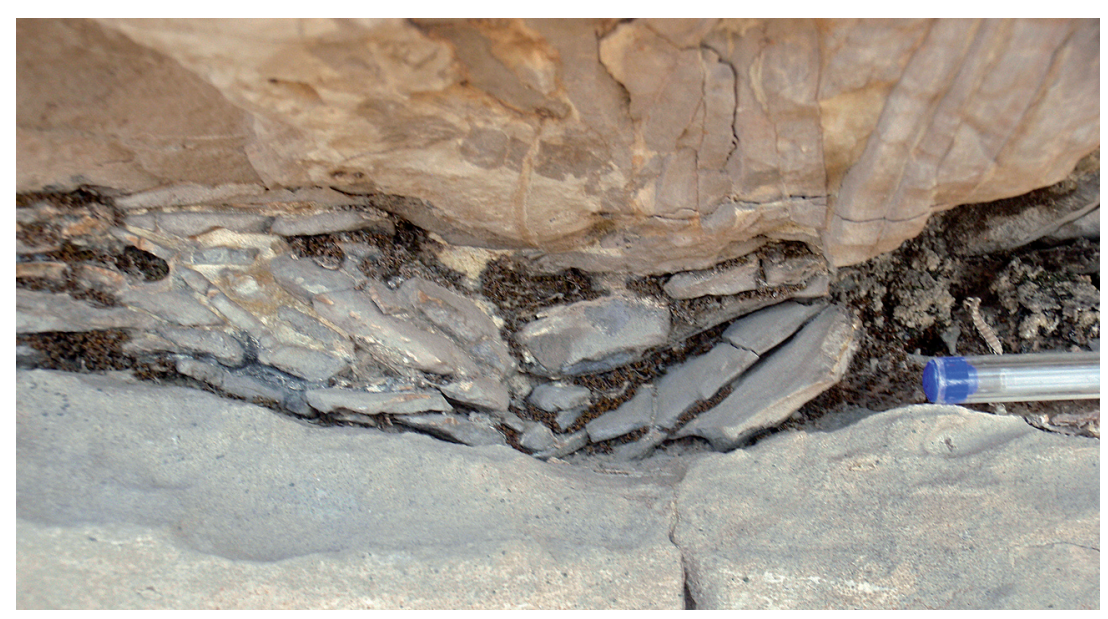




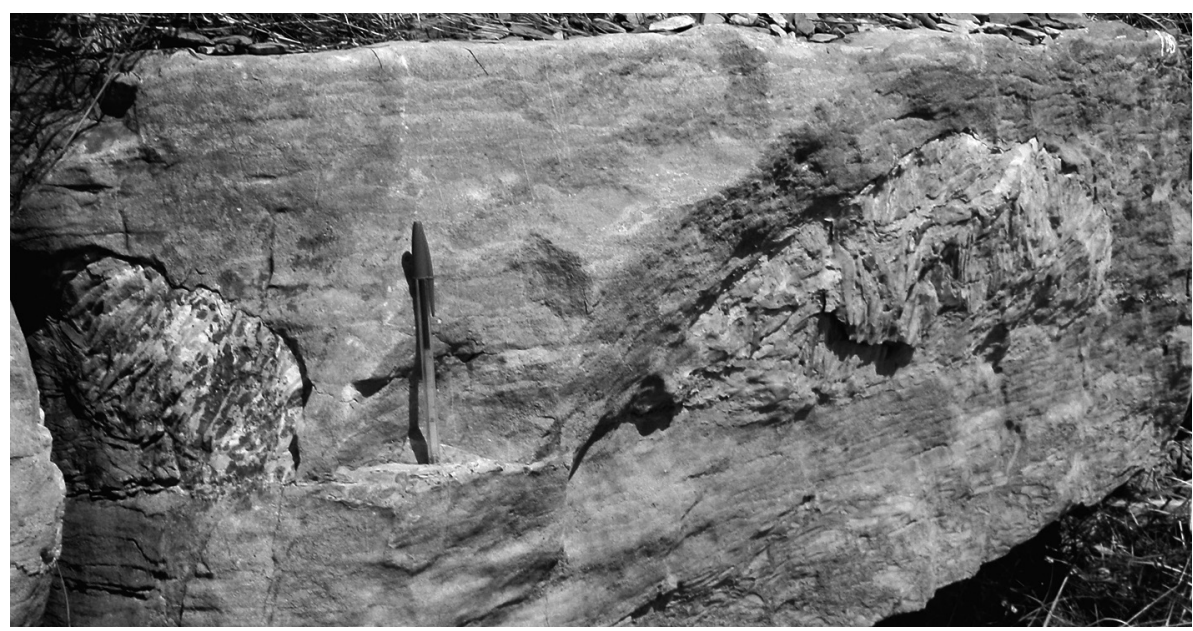

Fig. 9. Eastern end of Lens 4, where a roughly N-S orientated exposure is present perpendicular to the main E-W trending exposure, allowing a rough estimate of the elongation direction of the lens.

The thinning of the tails results from fragmentation. It appears that the individual fragments decrease in average size from the lens body to the end of the tail. Moreover, the farther away from the lens body, the less fragments tend to form the tail, until only small isolated fragments are left at the base level of the lenses. Eventually, only a horizon with some particles remains; these have a 'lens composition', but a few particles with a composition that is similar to that the oolite may also be present. This horizon can be traced from lens to lens, thus proving that the bases of all lenses are situated in the host oolite at the same level.

\subsection{Characteristics of the shear plane}

A chaotic zone is present beneath lenses 1, 3 and 4 (Fig. 8). It consists of clast-supported angular fragments that represent both the material from the underlying oolite layer and that of the breccia lenses; in between these clasts, a badly sorted matrix is present that is - as far as can be observed in the field - derived from the same sources. The clasts show a chaotic fabric (though almost all fragments have a horizontal to subhorizontal position) and it seems that at some places concentrations exist of clasts derived from the lenses, whereas clasts derived from the material below seem to predominate at other places. This zone thus shows, though at a much smaller scale, the same characteristics as the shear zones found under large overthrusts ('nappes') like in, for instance, the Alps.

\section{Genetic interpretation}

Lens-shaped sedimentary bodies (in crosssection) are common in stratigraphic successions and they may have many origins. The most common lenticular bodies are (1) channel deposits, particularly in the case of relief inversion due to differential compaction (Van Loon et al., 2012); (2) megaripples/dunes (Martinius \& Van den Berg, 2011); (3) slump masses (Martinsen, 2003), and (4) reefs or bioherms (Kiessling, 2003). Less common are (5) lifted/ transported sediment blocks (Van Loon \& Wiggers, 1976) and (6) horizontal intrusions (sedimentary sills) (Hiscott, 1979; Parize \& Fries, 2003; Whitmore \& Strom, 2010). The characteristics of the breccia lenses under study cannot be explained by invoking these mechanisms, as will be shown in Section 5.1 (Alternative explanations).

Taking into the occurrence of tails and of shear zones underneath the lenses, it is proposed that movement of brecciated material relative to an oolitic substratum took place. This cannot have been a tectonic movement, as only one layer is involved, and since this layer does not show any characteristics of a seismite. Thus some kind of mass transport of semi-consolidated material is the only possibility. The transport must have occurred over the sedi- 
mentary surface that is now still traceable as the horizon that connects the bases of the various lenses and on which isolated breccia and oolite clasts can be found. The breccia lenses themselves, however, do not show any evidence of transport in the form of a debris flow or another type of mass flow (the various lenses are all positioned horizontally at exactly the same level in the host oolite), but rather appear to have been transported as bodies in a (semi) consolidated state. Taken all evidence together, it must thus be deduced that the transport took place in the form of subaqueous sliding of breccia bodies over an oolite-covered seafloor.

Similar lenses are hardly known from other stratigraphic levels in this formation. However, one comparable lens has been found in an oolite at a few metres above the horizon under study here and another one has been found at a distance of several hundreds of metres from the study site at a level that cannot be correlated precisely enough with that of the lenses under study. It is consequently unlikely that several sliding events took place after each other over the same sedimentary surface. We interpret the present situation therefore as the consequence of a single sliding event of a block of semi-consolidated breccia. During the sliding process, the block broke apart (Fig. 10). Because there were most likely some irregularities at the sedimentary surface (for instance current-induced scours, or microbial buildups), the sliding must locally have resulted in the formation of a shear zone at the contact between the sliding blocks and the substratum, even though a water film may have facilitated the movement. One might compare the process with the sliding of a piece of crumbly cake from an inclined plate with some rippling: when the cake meets a ripple, a crack will develop, and at the next ripple this crack may result in breaking off of a piece of cake. The more ripples are passed, the more fragments originate and the more small crumbles become isolated from the larger fragments. Eventually the whole plane will show dispersed crumbles (comparable to the isolated clasts on the plane that connects the bases of the individual lenses.

This does, obviously, not explain the shear zone under the lenses, but one can imagine

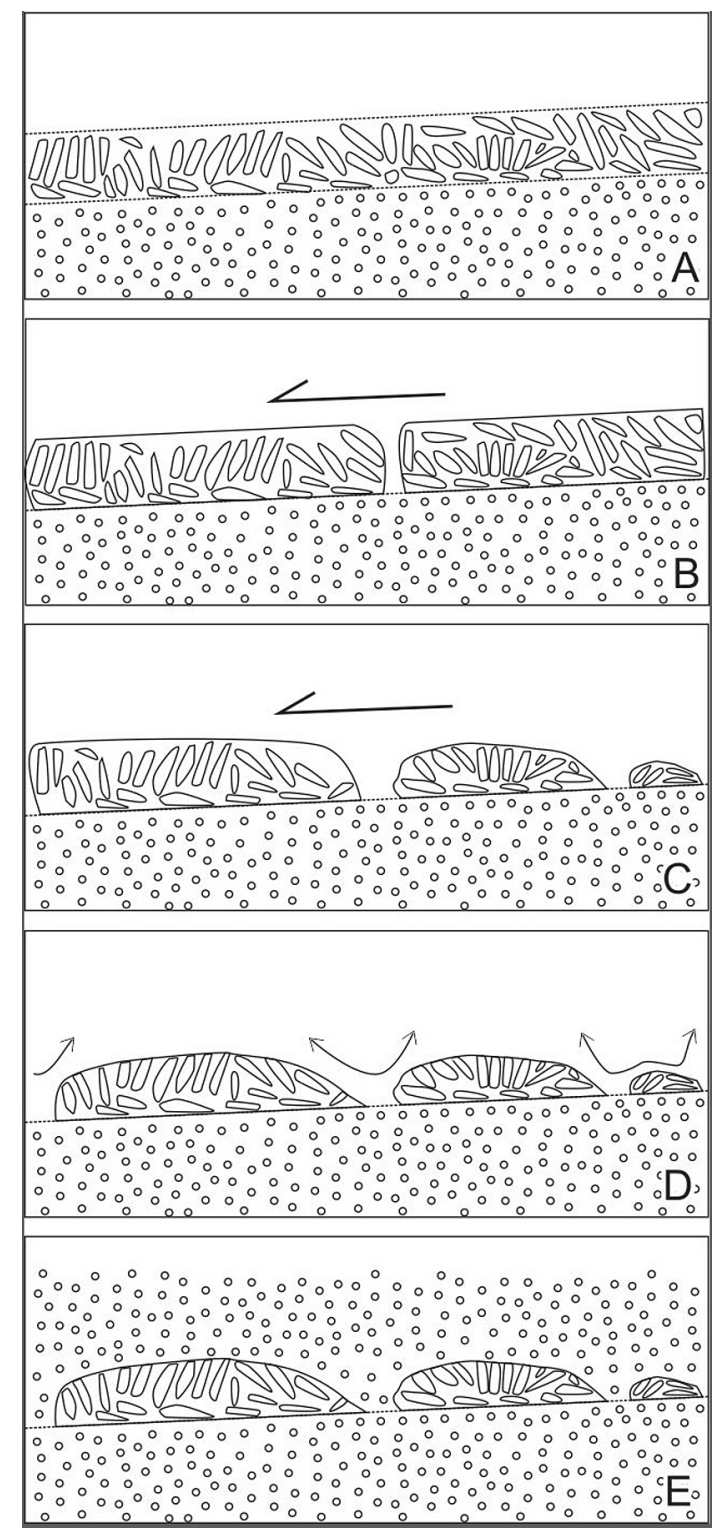

Fig. 10. Genetic model of the breccia lenses.

A: Formation of a breccia layer.

B: Initial break-up and subsequent sliding along a very shallow inclined surface of oolite.

C: Further break-up during sliding.

D: Abrasion by waves after sliding of the breccia lenses stopped.

E: Burial by ongoing accumulation of the host oolite.

that such a shear zone is formed when the cake does not slide down from a plate, but from the top of another cake with some cream (to facilitate the sliding) and some cherries (reflecting an irregular sedimentary surface) on top. The sliding took most probably place in a direction roughly from towards $295^{\circ}$ (uncorrected for tectonic tilt because the layers are almost horizontal), as indicated by the 3-D configuration 
of Lens 3, in combination with the fact that the tails of the lenses have a directional component towards the east.

\section{Discussion}

The North China Platform was a typical epeiric platform during the Late Cambrian (Meng et al., 1997), which is a low-relief environment where sliding is not typically expected. Nevertheless, sliding seems the only satisfactory explanation, because all other known geological processes and mechanisms that might explain the shape, position and characteristics of the lenses appear inadequate, as will be detailed here.

\subsection{Alternative explanations}

Several alternative explanations for the genesis of the lenses were mentioned in the chapter about the genetic interpretations. These alternatives were rejected for the following reasons.

(1) An origin as channel fills can be excluded for two main observations: (a) the base of the lenses is horizontal while the top is convex, which cannot be ascribed to differential compaction, because the oolite does not show more compaction than the breccias, and (b) the vertical position of a large number of clasts is not consistent with channel filling.

(2) An origin as megaripples (dunes) can be excluded because (a) the clasts should preferentially be orientated according to the lee-side inclination, and (b) a megaripple with a length of some $12 \mathrm{~m}$ is difficult to explain in the shallow environment of an epeiric sea; moreover, no megaripples are found elsewhere in this section of the Chaomidian Formation.

(3) An origin as slump masses cannot be fully excluded, but slumping includes rotational movement, whereas the fabric of the clasts in the lenses suggests a more rigid (semi-consolidated) behaviour of the breccia body because the clasts did not re-orientate according to a flowage pattern (cf. Van Loon, 1983).

(4) The breccia lenses are neither metazoan reefs nor microbial mounds in origin, although some microbial infilling between some of the clasts is present. These constitute, however, minor components. Moreover, talus from a microbial mound is unlikely to be composed of mainly vertically oriented fragments.

(5) It is known that blocks of water-saturated sediment with a mass comparable to that of water (e.g., peat) can be uplifted by waves, transported over some distance, and deposited elsewhere (Van Loon \& Wiggers, 1976), but (a) (semi)consolidated breccias are too heavy, (b) such an origin could not explain the tails of most lenses, nor (c) the sharp horizon connecting the bases of the breccia lenses; and (d) such an origin could not explain the shear zone under most breccia lenses.

(6) An origin as a sedimentary sill (dike) is excluded because (a) the clasts would show a preferential orientation according to the flow lines (like crystals carried along in an intruding magmatic vein) whereas, in the lenses, the clasts form clusters with other orientations; (b) an intrusion would neither explain the flat lower boundaries of the lenses, nor the tails consisting of isolated clasts. In addition, only the clasts in the upper (convex) margin of breccia lenses are truncated, which indicates that the breccia lenses were abraded after emplacement. This truncation implies that the lenses either have been exposed at the sedimentary surface or that they were positioned at such a shallow depth that wave action could abrade their topmost parts (the latter option is by far the most likely, as no signs of emergence have been found at this level in the wide surroundings). Subaerial deposition of the lenses would, however, imply that the 'intrusion' would have taken place at the sedimentary surface, which is mutually inconsistent and can thus be neglected. Horizontal intrusion of the oolite by a fluidized lime mud mass seems, however, not possible either, as explained in the arguments (a) and (b) above. An origin as sill is therefore not feasible.

Considering the mechanisms that might explain the genesis of the lenses, it seems that only a slump origin cannot be fully excluded. However, a slump requires plastic behaviour and would have most likely resulted in deformed (rotated, contorted, or overturned) 
bedding inside the slump mass (Martinsen, 2003). The clasts do, however, not show any evidence of mutual displacement during slumping, but have retained a fabric similar to that in non-slumped breccias of the Chaomidian Formation which resulted from re-orientation by upward escape of pore water and fluidized sediment (Chen et al., 2009a; Van Loon et al., in press); it must therefore be concluded that the breccia lenses were at least semi-consolidated (this can also be deduced from the rounding of many of the clasts). If the mechanisms described above were not responsible for the formation of the breccia lenses inside the oolite, sliding of (semi)consolidated blocks is the only satisfactory process that can explain the various characteristics detailed above.

\subsection{Required inclination of the slide plane}

Sliding on a carbonate ramp has been reported before (Pedley et al., 1992), but this sliding was ascribed to seismic shocks. No indications for seismic activity have been found in the section under study here. Therefore, specific conditions must, for at least one time during the long depositional history of the Chaomidian Formation, have initiated the breaking off of a breccia layer that then started to slide down along a very low-gradient sedimentary surface.

This latter aspect does not pose a problem because even a very gentle slope is sufficient for mass transport (Gibert et al., 2005; Moretti \& Sabato, 2007; Alsop \& Marco, 2011); examples of slumping and sliding over near-horizontal sedimentary surfaces (in other environments) have been described several times, also for inclinations of less than $1^{\circ}$ (e.g. García-Tortosa et al., 2011) and even less than $0.25^{\circ}$ (Field et al., 1982). Very low-angle movement has also been demonstrated experimentally (Owen, 1996).

\subsection{Fragmentation of the breccia layer}

Animportantquestioniswhichmechanism(s) triggered the initial break-up and subsequent sliding of the breccia layer. Several mechanisms can do so in principle; they include overloading, tsunamis, earthquakes, storms, and sealevel fluctuations (Spence \& Tucker, 1997; Kullberg et al., 2001; Moretti \& Sabato, 2007; Van Loon, 2009). As mentioned above, no evidence of seismic activity is present, which excludes an earthquake. No signs of a tsunami are present either, and the sediments below and above the host oolite of the breccia lenses do not indicate rapid sea-level fluctuations. This leaves cyclic wave overloading by storm-induced waves as the most likely trigger; this is consistent with the restricted lateral occurrence of the breccia lenses (probably a few $\mathrm{km}^{2}$ ).

Another question is why only one layer hosts a number of slid-down breccia blocks (we found only one - badly exposed - layer a few metres higher with just one such block; and one isolated slid-down block a few hundred metres further at a not precisely known level in the formation). In our opinion, this question should not be asked this way: because descriptions of comparable features are extremely rare (Pedley et al., 1992), the question should be why several blocks occur that slid down over the bottom of an epeiric sea. Since there are no clues from the field, an answer can be only speculative. Considering the many layers in the succession that have been broken up, storms must have been relatively frequent. Present-day observations indicate that storms with a specific power/ magnitude decrease exponentially in number with increasing power/magnitude. Since the Chaomidian Formation covers more or less the entire Furongian (which lasted approx. 12 million years), some extremely heavy storms must have occurred. Having no other clues, we consider the sliding of the breccia block (and its subsequent fragmentation) therefore as the probable result of cyclic overloading due to extremely heavy storms.

\subsection{Geographical source area}

The source of the breccia lenses must have been a breccia layer that has the characteristics mentioned above. Since such breccias are common (dozens in this section), this does not 
pose any problem: numerous breccias of this type are present in the Chaomidian Formation, also under the layer with the lenses. It can, unfortunately, not be checked whether a layer exists from which a large piece was broken off; the reason is that the transport direction, as deduced from the only 3-D outcrop, indicates that the source area must have been located in a direction (probably $\sim 115^{\circ}$ ) where no hills are present that reach to this stratigraphic level. Considering the shear zone below several of the blocks, the sliding blocks must have met fairly much resistance. It is therefore likely that the transport distance was small (possibly only a few hundreds of metres or even less).

The various features that occur in, or associated with, the breccia lenses are summarized in an emplacement model (Fig. 10). Breccias of the type that make up the lenses described here are common throughout the Chaomidian Formation (Chen et al., 2009a, 2011). If, for one reason or another (such as instability due to differential compaction or storm wave loading), a part breaks off and starts to slide down, smaller parts may more easily break off, as explained in Chapter 4. This explains the 'series' of breccia lenses. Sliding takes place over the sedimentary surface, and the clear continuous horizon that can be distinguished between the bases of the laterally present lenses represents this palaeosurface. Local friction with the underlying oolite (most probably because the bases of the various breccia fragments were not entirely flat due to irregularities formed due to the re-orientation of the clasts that took place when the breccia became liquified during a phase that occurred possibly long before the sliding took place: $\mathrm{cf}$. Van Loon et al., in press) explains the shear zones. The semi-consolidated breccia fragments retained their internal fabric during sliding, but resistance at their front led to the irregularities in the shape of the breccia 'front'. Friction with the substratum led to the fragmentation of some material at the base of the sliding blocks, so that a tail was formed, as in the case of a slump.

\section{Acknowledgements}

This study was supported by the National Natural Science Foundation of China (40972043 and
41040018), the Ph.D. Programs Foundation of the Ministry of Education of China (20093718110001), and the SDUST Research Fund (2010KYTD103).

\section{References}

Alsop, G.I. \& Marco, S., 2011. Soft-sediment deformation within seismogenic slumps of the Dead Sea Basin. Journal of Structural Geology 33, 433-457.

Bouchette, F., Seguret, M. \& Moussine-Pouchkine, A., 2001. Coarse carbonate breccias as a result of waterwave cyclic loading (uppermost Jurassic-South-East Basin, France). Sedimentology 48, 767-789.

Chen, J., Chough, S.K., Chun, S.S. \& Han, Z., 2009a. Limestone pseudoconglomerates in the Late Cambrian Gushan and Chaomidian Formations (Shandong Province, China): soft-sediment deformation induced by storm-wave loading. Sedimentology 56, 1174-1195.

Chen, J., Van Loon, A.J., Han, Z. \& Chough, S.K., 2009 b. Funnel-shaped, breccia-filled clastic dykes in the Late Cambrian Chaomidian Formation (Shandong Province, China). Sedimentary Geology 221, 1-6.

Chen, J., Han, Z., Zhang, X, Fan, A. \& Yang, R., 2010. Early diagenetic deformation structures of the Furongian ribbon rocks in Shandong Province of China - a new perspective of the genesis of limestone conglomerates. Science China, Earth Sciences 53, 241-252.

Chen, J., Chough, S.K., Han, Z. \& Lee, J.H., 2011. An extensive erosion surface of a strongly deformed limestone bed in the Gushan and Chaomidian Formations (late Middle Cambrian to Furongian), Shandong Province, China: sequence-stratigraphic implications. Sedimentary Geology 233, 129-149.

Chen, J., Chough, S.K., Lee, J.H. \& Han, Z., 2012. Sequence-stratigraphic comparison of the upper Cambrian Series 3 to Furongian succession between the Shandong region, China and the Taebaek area, Korea: high variability of bounding surfaces in an epeiric platform. Geosciences Journal 16, 357-379.

Chough, S.K., Kwon, Y.K., Choi, D.K. \& Lee, D.J., 2001. Autoconglomeration of limestone. Geosciences Journal $5,159-164$

Chough, S.K., Lee, H.S., Woo, J., Chen, J., Choi, D.K., Lee, S.-B., Kang, I., Park, T.-Y. \& Han, Z., 2010. Cambrian stratigraphy of the North China Platform: revisiting principal sections in Shandong Province, China. Geosciences Journal 14, 235-268.

Field, M. E., Gardner, V., Jennings, A.E. \& Edwards, B.D., 1982. Earthquake-induced sediment failures on a $0.25^{\circ}$ slope, Klamath river delta, California. Geology $10,542-546$.

García-Tortosa, F.J., Pedro Alfaro, P., Gibert L. \& Scott, G., 2011. Seismically induced slump on an extremely gentle slope $\left(<1^{\circ}\right)$ of the Pleistocene Tecopa paleolake (California). Geology 39, 1055-1058.

Gibert, L., Sanz De Galdeano, C., Alfaro, P., Scott, G. \& Lopez Garrido, A.C., 2005. Seismic induced slump in Early Pleistocene deltaic deposits of the Baza Basin (SE Spain). Sedimentary Geology 179, 279-294. 
Hiscott, R.N., 1979. Clastic sills and dikes associated with deep-water sandstones, Tourelle Formation, Ordovician, Quebec. Journal of Sedimentary Petrology 49, 1-10.

Kiessling, W., 2003. Reefs [In:] G.V. Middleton (Ed.): Encyclopedia of sediments and sedimentary rocks. Kluwer Academic Publishers, Dordrecht, 557-560.

Kullberg, J.C., Oloriz, F., Marques, B., Caetano, P.S. \& Rocha, R.B., 2001. Flat-pebble conglomerates: a local marker for Early Jurassic seismicity related to syn-rift tectonics in the Sesimbra area (Lusitanian Basin, Portugal). Sedimentary Geology 139, 49-70.

Kwon, Y.K., Chough, S.K., Choi, D.K. \& Lee, D.J., 2002. Origin of limestone conglomerates in the Choson Supergroup (Cambro-Ordovician), mid-east Korea. Sedimentary Geology 146, 265-283.

Martinius, A.W. \& Van den Berg, J.H., 2011. Atlas of sedimentary structures in estuarine and tidally-influenced river deposits of the Rhine-Meuse-Scheldt system - their application to the interpretation of analogous outcrop and subsurface depositional systems. EAGE Publications, Houten, 298 pp.

Martinsen, O.J., 2003. Slide and slump structures. [In:] G.V. Middleton (Ed.): Encyclopedia of sediments and sedimentary rocks. Kluwer Academic Publishers, Dordrecht, 666-668.

Mei, M.X. \& Ma, Y.S., 2001. Study on sequence Stratigraphy and sea-level changes of Late Cambrian in northern part of North China - discussion on the correlation of sea-level change with that of North America. Journal of Stratigraphy 25, 201-206. [in Chinese, with English abstract]

Mei, S.L., Mei, M.X. \& Chen, J.Q., 1996. New results from the study on the outcrop sequence Stratigraphy of Middle and Upper Cambrian, North China. Journal of Stratigraphy 20, 146-152. [in Chinese, with English abstract]

Meng, X., Ge, M. \& Tucker, M.E., 1997. Sequence stratigraphy, sea-level changes and depositional systems in the Cambro-Ordovician of the North China carbonate platform. Sedimentary Geology 114, 189-222.

Meng, X.H., Qiao, X.F. \& Ge, M., 1986. Study on ancient shallow sea carbonate storm deposits (tempestite) in North China and Dingjiatan - model of facies sequences. Acta Sedimentologica Sinica 5, 1-18. [in Chinese, with English abstract]

Morawski, W., 2009. Neotectonics induced by ice-sheet advances in NE Poland. Geologos 15, 199-217.

Moretti, M. \& Sabato, L., 2007. Recognition of trigger mechanisms for soft-sediment deformation in the Pleistocene lacustrine deposits of the Sant'Arcangelo Basin (Southern Italy): seismic shock vs. overloading. Sedimentary Geology 196, 31-45.

Owen, G., 1996. Experimental soft-sediment deformation: structures formed by the liquefaction of unconsolidated sands and some ancient examples. Sedimentology 43, 279-293.

Parize, O. \& Fries, G., 2003. The Vocontian clastic dykes and sills; a geometric model. [In:] P. van Resenbergen,
A.J. Hillis \& C.K. Morley (Eds): Subsurface sediment mobilization. Geological Society, London, Special Publications 216, 51-72.

Pedley, H.M., Cugno, G. \& Grasso, M., 1992. Gravity slide and resedimentation processes in a Miocene carbonate ramp, Hyblean Platcau, southeastern Sicily. Sedimentary Geology 79, 189-202.

Shi, X.Y., Chen, J.Q. \& MEI, S.L., 1997. Cambrian sequence stratigraphic framework of the North China Platform. Earth Science Frontiers 4, 161-172. [in Chinese, with English abstract]

Spalluto, L., Moretti, M., Festa, V. \& Tropeano, M., 2007. Seismically-induced slumps in Lower-Maastrichtian peritidal carbonates of the Apulian Platform (southern Italy). Sedimentary Geology 196, 81-98.

Spence, G.H. \& Tucker, M.E., 1997. Genesis of limestone megabreccias and their significance in carbonate sequence stratigraphic models: a review. Sedimentary Geology 112, 163-193.

Spengler, A.E. \& Read, J.F., 2010. Sequence development on a sediment-starved, low accommodation epeiric carbonate ramp: Silurian Wabash Platform, USA midcontinent during icehouse to greenhouse transition. Sedimentary Geology 224, 84-115.

Van Loon, A.J., 1983. The stress system in mud flows during deposition, as revealed by the fabric of some Carboniferous pebbly mudstones in Spain. [In:] M.W. van den Berg \& R. Felix, R. (Eds): Special issue in honour of J.D. de Jong. Geologie en Mijnbouw 62, 493-498.

Van Loon, A.J., 2009. Soft-sediment deformation structures in siliciclastic sediments: an overview. Geologos 15, 3-55.

Van Loon, A.J. \& Wiggers, A.J., 1976. Primary and secondary synsedimentary structures in the lagoonal Almere Member (Groningen Formation, Holocene, The Netherlands). Sedimentary Geology 16, 89-97.

Van Loon, A.J., Han, Z. \& Han, Y. (in press). Origin of the vertically orientated clasts in brecciated shallow-marine limestones of the Chaomidian Formation (Furongian, Shandong Province, China). Sedimentology (in press).

Van Loon, A.J., Mazumder, R. \& De, S., 2012. Unravelling the depositional environment of the Archaean Rajkharsawan conglomerate (Jharkhand, eastern India). Netherlands Journal of Geosciences / Geologie en Mijnbouw 91, 103-109.

Wang, Y.H., Zhang, X.L. \& Yang, C.Y., 1989. Carbonate petrology of the Early Palaeozoic in the North China Platform. Earthquake Publishing House, Beijing, 50 pp. [in Chinese]

Whitmore, J.H. \& Strom, R., 2003. Sand injectites at the base of the Coconino Sandstone, Grand Canyon, Arizona (USA). Sedimentary Geology 230, 46-59.

Manuscript received: 25 September 2012 Revision accepted: 4 November 2012 